計出増ぼ降表四を速は，云 殊の率定出 1 し年勢一\% 九 出動がし生にてををい時とで七 生向つて率示き境なで的なあ九 率をいいのさてにし人るる年

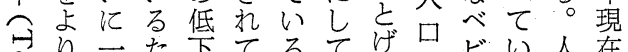
仓り

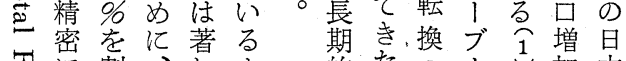

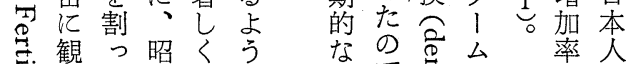

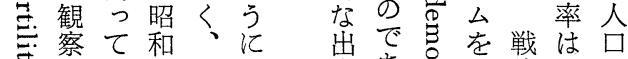

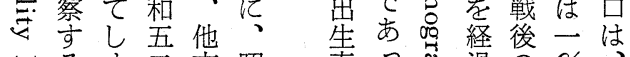
严ま主方昭率た過の \%

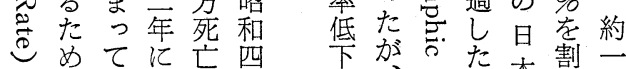

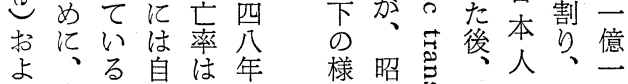
び合。然ほ以相和鱼口急口五

めるず吕が潜て位表寿 ら。れ。在い四命とて置を再 れ出老异そ的る。占ののいき割み生 る生齢このなる 女る伸よる換つる産

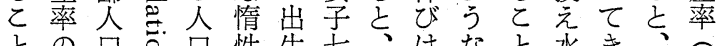

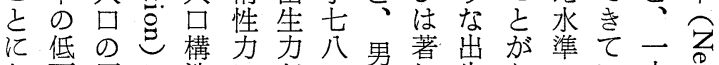

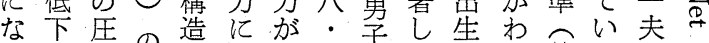

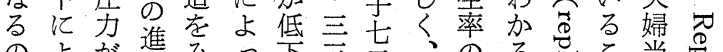

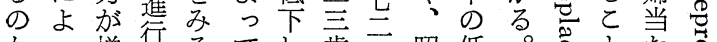
かつ増行るてし歳 昭低 屯て守明文徐て合九和下 しそと公方同五に れのと吕に総第歳言氻 な時が㤎增人四年加 い期予あ齢加口位世のわ 低一測り华主人と界簡占 出層さ、品、い口な第生平 生早れい吉るのっ命均

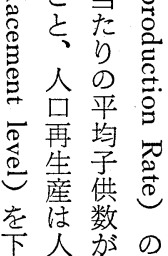

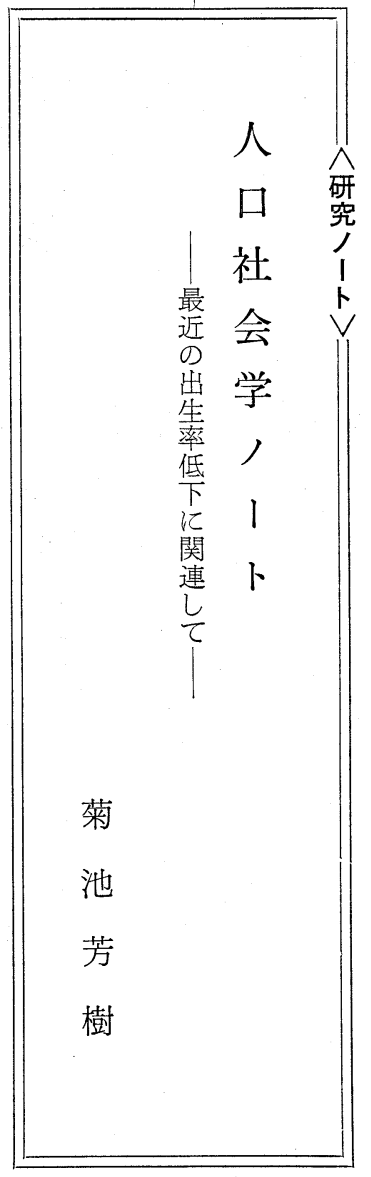

表 1 最近の出生率と死亡率

\begin{tabular}{c|c|c|c|c}
\hline 昭 和 & 出生率 & 死亡率 & T F R & N R R \\
\hline 45 年 & 18.8 & 6.9 & 2.135 & 1.004 \\
46 年 & 19.2 & 6.6 & 2.157 & 1.019 \\
47 年 & 19.3 & 6.5 & 2.142 & 1.013 \\
48 年 & 19.4 & 6.6 & 2.140 & 1.014 \\
49 年 & 18.6 & 6.5 & 2.049 & 0.970 \\
50 年 & 17.1 & 6.3 & 1.909 & 0.908 \\
51 年. & 16.3 & 6.3 & 1.852 & 0.882 \\
52 年 & 15.5 & 6.1 & 1.801 & 0.858 \\
\hline
\end{tabular}

注） TFR：合計特殊出生率。NRR：純再生産率。

資料）安川正涁「やさしい人口学教室」p.196より作成。
半率ナなのッみで率 汃加欧、出市の ら河で米イ机生る問 低召転す諸ギる率と題 下茜西国り。低いは しのてドでス下下え、 始推いイむ、九のよ人 め移るッ出不六現う。 てを。の生ウ○象 い及西人率工年は るド口が!代

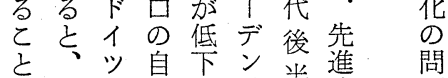
が一の然し、半諸題 わ九合増て了か国

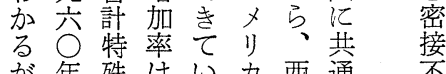
が年殊はい力西通杯

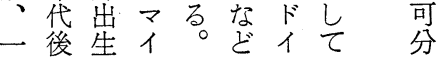




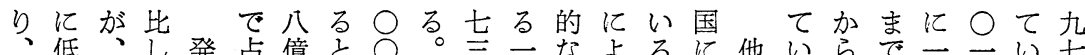
、低、し発占億と○。主ななるに他いらで一一い七 人下日て展め四推年し年九出って㧍方るの下・でる。 口し本い途ら八計のか推七生てとい、。西吕五あ。年 学てをま上れ 者き含だ地る○机界、よ年低ら国も口ててて降 のてめ高域で万、人こりの方加連、爆ツいなが七さ みい先率のあのそロのも世のにの徐発

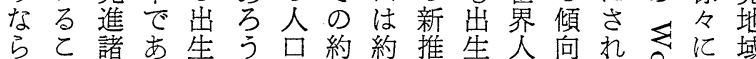
ず国る率とは六計率口をて出と 各はのをは予発八二にを将察いる生呼 方明出い先测展％億よ低来知る。率ば 面ら生わ進さ途、九っく推し。がれ 加率ざ地れ上す六て仮計てこ寻低る

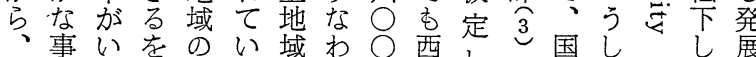

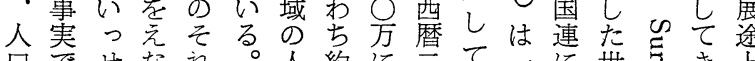

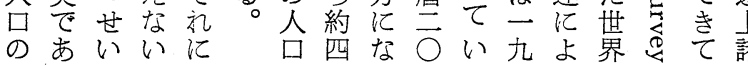
はるり、○ ら 厓吾 七年に 界年年合の で七にに計低 む ○は一特 下 超 年つ・殊 速. 少代い七出度 産にに一生㤎 国は一、率 加 とい・ 七は速 なっ四三三さ

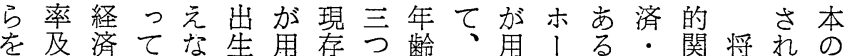

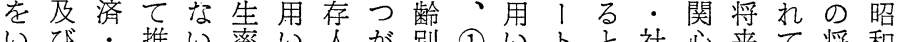
か出社計のにら者死現ら要い会少来て将和 に生会結てつれと要亡存れ园え政ら口る人○ 仮率的果、いるし不率人て法る策の推

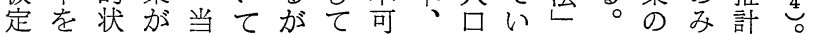
す仮況大然は、国欠(3)する。人基なは る定をきな娄将勢で出な。完盤さ 加し予々がく来調あ生わ推名推子机単 がな測異らまの査る率ち計る計なるに

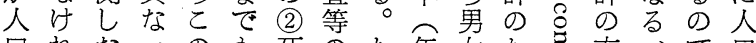
口れなっのす死のた年女た莺方心゙で口 推ばがて仮仮它既だ㱓年めす法きは学 計ならく定定率知し別龄の『と重なに のら将るのでなの、出別デ怘要くお

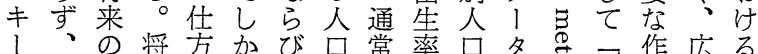

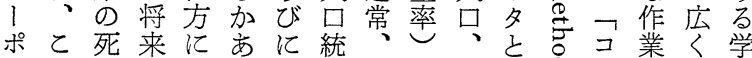
1 れ亡 のより (3) 計 (1) の (2) し き 1 で経問

推 国 計 勢 が、調 この れ人年 ま口統口 で 統

い計

らを

加以

公た
明 将 す 来 る 予 乙 测 に $\sum_{\text {最 }}$ 大近 きに なみ 関 ら 心 れ がる

寄 低 女出 ら生 れの て 原 心因 る 解

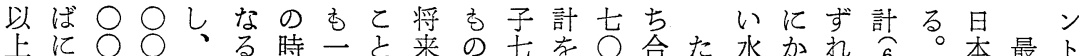

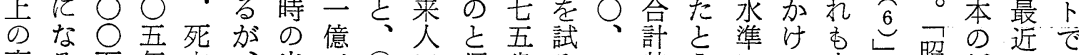
高る方年亡 、出意 (2) 口仮歳み一特えにて出で昭将のあ 齢乙の以率こ生つとは定、て・殊ば置公生で和来出る 者之現降は橿○の酉し女い六出ᄀい表率方吾人生之 は在に上以卡時糜て尒五生安てさのる年品い

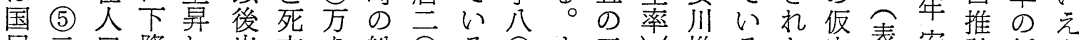
民二口降し出亡を総 $\vec{\bigcirc}$ るま三推るた定表安計低よ の二ににて生率超人○歳たうの計の他を 五世な転い率はえ口五推ま平の仮尔の昭。推す傾 人紀るじくはとなは年計で均低定は特推和こ計で向 ににのると低すい最にのゆ寿いを、徵計五れ計にを

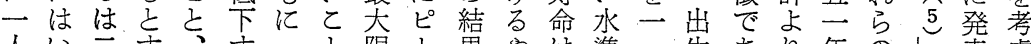

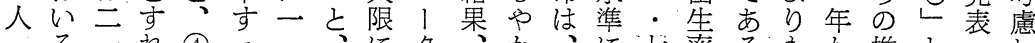
る二れ (4)る一、にク加、に率るす推とさし

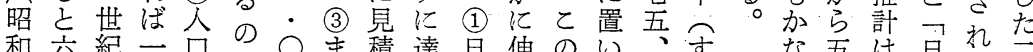

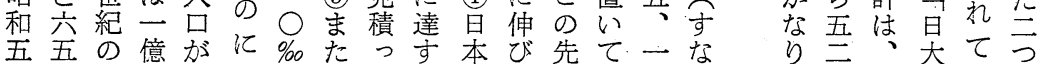

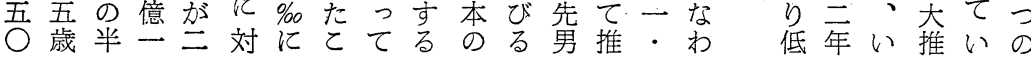




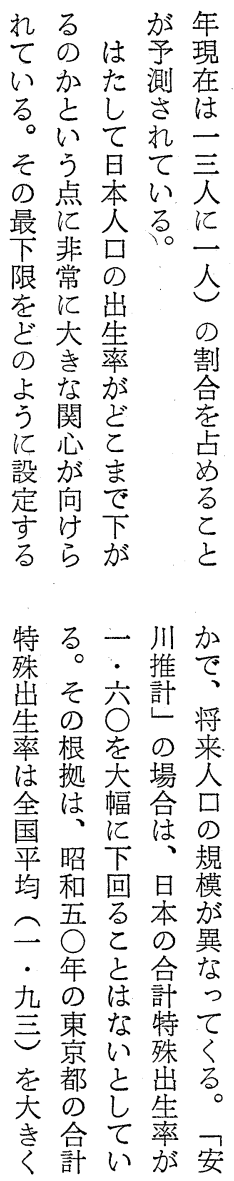

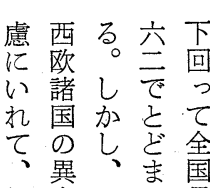

低常 $つ$ 最

位と日て低

推市大心文

計思推るな

亡充計事?

て出の春い

合生場ある

計率合之字

特のはめの

殊 低、らの

出尘を邀て一

表 2 最近の将来人口推計の結果

(単位：千人)

\begin{tabular}{|c|c|c|c|c|c|}
\hline \multirow{2}{*}{ 昭 和 } & \multirow{2}{*}{ 西 曆 } & \multirow{2}{*}{$\begin{array}{c}\text { 参考推計 } \\
1.45 \text { 児 }\end{array}$} & \multicolumn{3}{|c|}{ 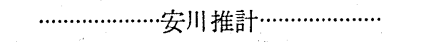 } \\
\hline & & & 1.65児 & 1.70児 & 1.75児 \\
\hline 50 年 & (1975) & 111,895 & 111,895 & 111,895 & 111,895 \\
\hline 55 年 & 80 & 116,223 & 116,669 & 116,787 & 116,892 \\
\hline 60 年 & 85 & 118,424 & 119,737 & 120,079 & 120,390 \\
\hline 65年 & 90 & 119,870 & 122,019 & 122,568 & 123,085 \\
\hline 70年 & 95 & 120,961 & 123,954 & 124,709 & 125,445 \\
\hline 75年 & $(2000)$ & 121,698 & 125,590 & 126,566 & 127,534 \\
\hline 80 年 & 05 & 121,316 & 126,227 & 127,473 & 128,696 \\
\hline 85 年 & 10 & 119,183 & 125,268 & 126,833 & 128,359 \\
\hline 90 年 & 15 & 115,663 & 122,992 & 124,896 & 126,753 \\
\hline 95 年 & 20 & 111,422 & 119,998 & 122,233 & 124,439 \\
\hline 100年 & 25 & $※ 106,846$ & 116,678 & 119,254 & 121,819 \\
\hline 105年 & 30 & 101,965 & 113,094 & 116,031 & 118,964 \\
\hline 110 年 & 35 & $※ ※ 96,734$ & $※ 109,195$ & 112,515 & 115,825 \\
\hline 115年 & 40 & 91,275 & 105,066 & $※ 108,780$ & 112,476 \\
\hline 120 年 & 45 & 85,817 & 100,895 & 104,994 & $※ 109,083$ \\
\hline 125 年 & $(2050)$ & 80,509 & $※ ※ 96,808$ & 101,269 & 105,751 \\
\hline
\end{tabular}

(単位：千人)

\begin{tabular}{|c|c|c|c|c|c|}
\hline 昭 和 & 西 暦 & 高 位 & $\begin{array}{c}\text { 中 位 } \\
(1.80 \rightarrow \\
1.65 \text { 児 })\end{array}$ & $\begin{array}{c}\text { 低 位 } \\
(1.80 \rightarrow \\
1.50 \text { 児 })\end{array}$ & 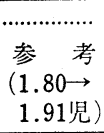 \\
\hline 50 年 & (1975) & 111,889 & 111,889 & 111,889 & 111,889 \\
\hline 55年 & 80 & 116,852 & 116,838 & 116,823 & 116,852 \\
\hline 60年 & 85 & 120,220 & 120,131 & 120,039 & 120,247 \\
\hline 65年 & 90 & 122,773 & 122,549 & 122,328 & 122,875 \\
\hline 70年 & 95 & 125,262 & 124,832 & 124,399 & 125,498 \\
\hline 75 年 & $(2000)$ & 127,830 & 127,104 & 126,383 & 128,264 \\
\hline 80 年 & 05 & 129,466 & 128,383 & 127,298 & 130,140 \\
\hline 81年 & 06 & 129,579 & 128,418 & 127,256 & 130,305 \\
\hline 82 年 & 07 & 129,634 & 128,393 & 127,155 & 130,415 \\
\hline 83 年 & 08 & 129,620 & 128,296 & 126,978 & 130,454 \\
\hline 84 年 & 09 & 129,535 & 128,127 & 126,722 & 130,429 \\
\hline 85年 & 10 & 129,390 & 127,894 & 126,402 & 130,340 \\
\hline 90 年 & 15 & 127,944 & 125,955 & 123,995 & 129,229 \\
\hline 95年 & 20 & 125,923 & 123,345 & 120,802 & 127,643 \\
\hline 100 年 & (2025) & 123,903 & 120,586 & 117,337 & 126,161 \\
\hline
\end{tabular}

注） 1) 太数字は各ピーク時の人口, ※は 1 億 1 千万人口に達する時点, ※※は 1 億人口に達する時点。

2 ) 参考推計 (1.45児) は获池に上る。

資料）「昭和53年安川推計」「日大推計」の発表レジュメより作成。 
のつに仮のて它し特ド国述将な一西たずすンれを 日て両定西たの四た殊イの芯来りなそる、机のをは一 本い国しドだで五が出ツなる人低推こか最でとと、.

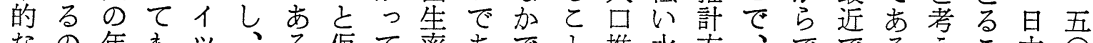

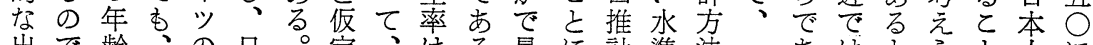
出で龃、の旦。定、はる最に計準法ᄀあはとらと人に

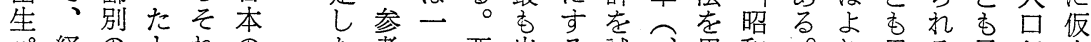
パ経のと机の考・西出る。試忿用和。り思る予が定 夕験出えと将, 日ま四ド生。み票い五一わ。想将し l的生ば同来、本で五イ率前だて言層れてささ来た ンにパ図じののにまッの述のた、年のななれ推 に明タ 1 值出将合での低しで出出少い前る西計 なら、にに生来計落一卡た、光生川産。提と欧を るかン示な率人特ち九市次に率推傾後方心型試 よでかしるが品殊込七著う江置の計向述あうのる うあ大てで一推出ん五しにそい仮し がすな前出て にるきああ九計生で年い、のた定と示るが提生い

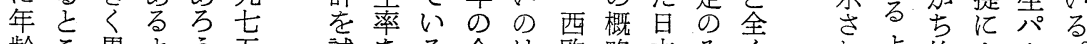
歯と異よう五試をる合は欧略本みく䏓よ的よ夕。 別ろなうと年み二。計西諸をのか同てうはるにと

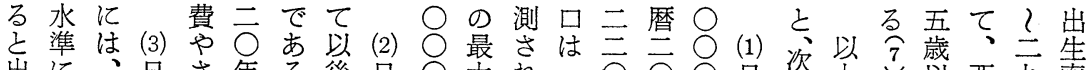

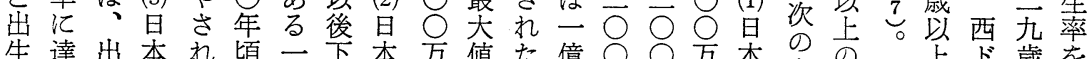
生達出本れ頃一下本万值た億 $\bigcirc \bigcirc$ 万本をの 上ド歳を

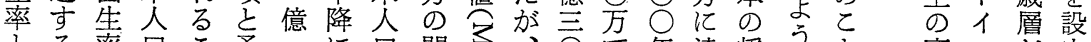

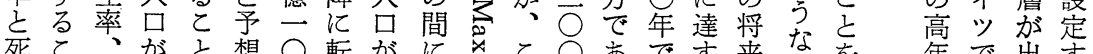
死と、がと想 ○転がに㐫と○市です来な結を年で出守

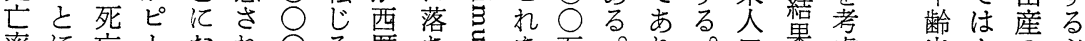

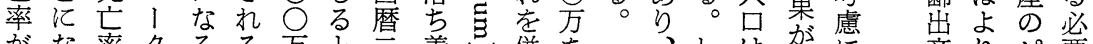

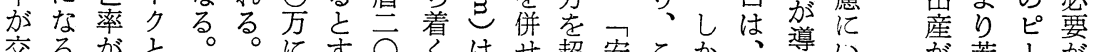

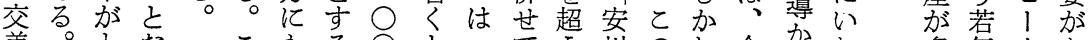

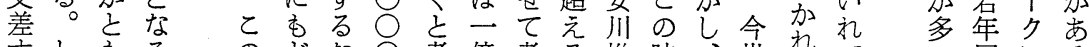

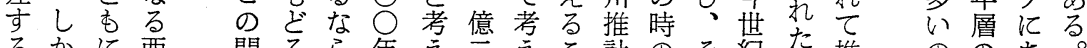
るかに西間るら年え云えと計のそ紀た推のののああ。 いし、曆四のばをら○るとし人のの表計出出た日

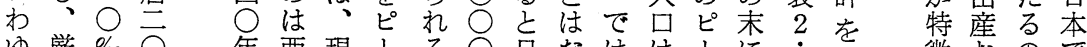
ゆ笅\%

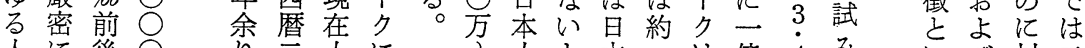

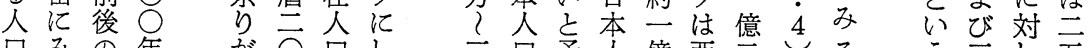
みの年加 $\overrightarrow{0}$ 口し 三予人億西意 $\underbrace{4}_{0}$ え

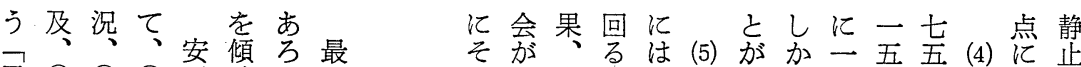

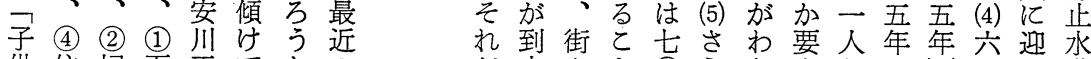
供住婦石正てか。の は宅人油彬みっ出三西す歩に歳にるず六はに歳らは 二事のシはよて生出ドるくな以注。、五三は以れ ま青垃 $ッ$ 最。机率出生 て (5)のク近関卡率社任供い人:

ட過向つの方の低会なのう品い

之密上昭出 る要卡のる姿とがの

认社、和 生

う会 (3) 四率

生会避八低

活認妊年卡

意識方以而理

識々法坚理

の毛のの先明て

転な普不し华售
人因はの淠吕をと仓は

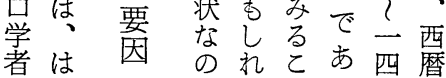

でなとる歳云

あ以永。人

る。稀そ吕五

さ社結上年
に口三九人

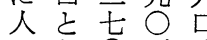

高なつ方は

齢。万昭年

化こにる和を

現の達が五号

象間守、五员

汃約る西年過

進四。糜气 ぎ

方年人五六 時 
表 3 年齢 3 区分推計人口（実数・割合）と各種指数： 1.45 児の仮定

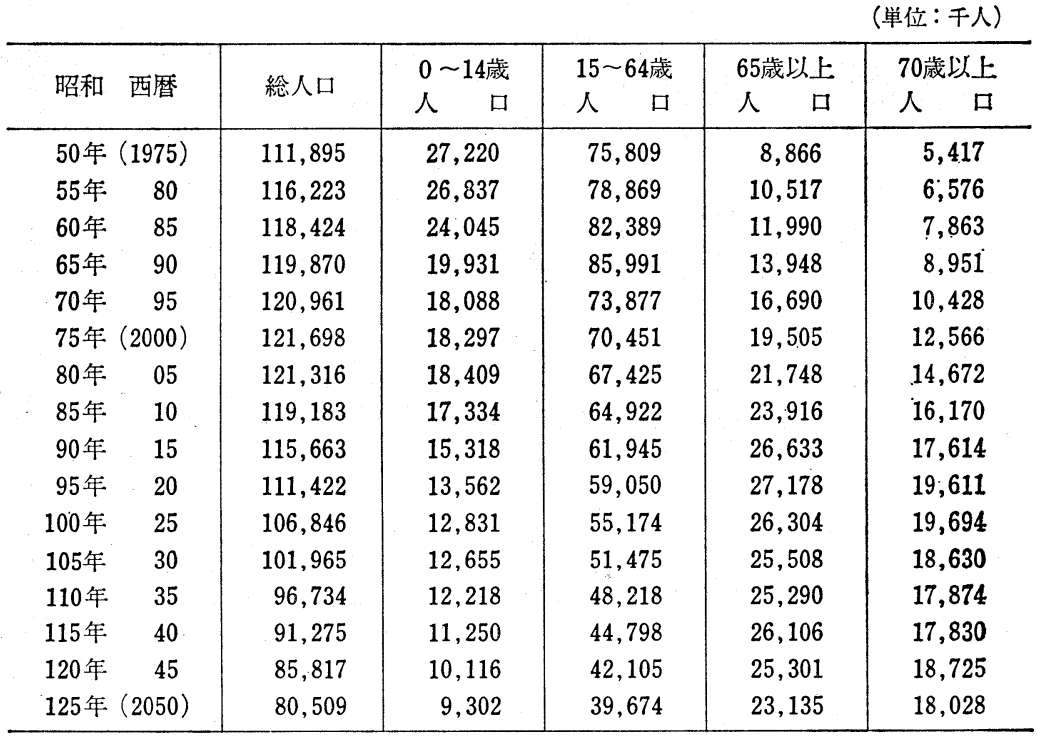

(\%)

\begin{tabular}{|c|c|c|c|c|c|c|c|c|}
\hline \multirow{2}{*}{\multicolumn{2}{|c|}{ 昭和 西暦 }} & $0 \sim 14$ 歳 & $15 \sim 64$ 歳 & 65歳以上 & 従属人口 & 年少人口 & 老年人口 & \multirow{2}{*}{$\begin{array}{l}\text { 老年化 } \\
\text { 指 数 }\end{array}$} \\
\hline & & 割 合 & 割 合 & 割 合 & 指 数 & 指 数 & 指 数 & \\
\hline \multicolumn{2}{|c|}{50 年 (1975) } & \multirow{2}{*}{$\begin{array}{l}24.33 \\
23.09\end{array}$} & 67.75 & 7.92 & 47.60 & 35.91 & 11.70 & 32.57 \\
\hline 55年 & 80 & & 67.86 & 9.05 & 47.36 & 34.03 & 13.33 & 39.19 \\
\hline 60年 & 85 & 20.30 & 69.57 & 10.12 & 43.74 & 29.18 & 14.55 & 49.86 \\
\hline 65年 & 90 & 16.63 & 71.74 & 11.64 & 39.40 & 23.18 & 16.22 & 69.98 \\
\hline 70年 & 95 & 14.95 & 61.08 & 13.80 & 47.08 & 24.48 & 22.59 & 92.27 \\
\hline 75年( & 2000) & 15.03 & 57.89 & 16.03 & 53.66 & 25.97 & 27.69 & 106.60 \\
\hline 80 年 & 05 & 15.17 & 55.58 & 17.93 & 59.56 & 27.30 & 32.26 & 118.14 \\
\hline 85 年 & 10 & 14.54 & 54.47 & 20.07 & 63.54 & 26.70 & 36.84 & 137.97 \\
\hline 90 年 & 15 & 13.24 & 53.56 & 23.03 & 67.72 & 24.73 & 42.99 & 173.87 \\
\hline 95年 & 20 & 12.17 & 53.00 & 24.39 & 68.99 & 22.97 & 46.03 & 200.40 \\
\hline 100 年 & 25 & 12.01 & 51.64 & 24.62 & 70.93 & 23.26 & 47.67 & 205.00 \\
\hline 105年 & 30 & 12.41 & 50.48 & 25.02 & 74.14 & 24.58 & 49.55 & 201.56 \\
\hline 110 年 & 35 & 12.63 & 49.85 & 26.14 & 77.79 & 25.34 & 52.45 & 206.99 \\
\hline 115年 & 40 & 12.33 & 49.08 & 28.60 & 83.39 & 25.11 & 58.27 & 232.05 \\
\hline 120 年 & 45 & 11.79 & 49.06 & 29.48 & 84.12 & 24.03 & 60.09 & 250.11 \\
\hline 125 年 ( & 2050) & 11.55 & 49.28 & 28.74 & 81.76 & 23.45 & 58.31 & 248.71 \\
\hline
\end{tabular}

従属人口指数 $=\frac{15 \text { 歳未満人口 }+65 \text { 歳人口 }}{15 \sim 64 \text { 藏人 }} \times 100$ 老年人口指数 $=\frac{65 \text { 歳以上人口 }}{15 \sim 64 \text { 歳人口 }} \times 100$

年少人口指数 $=\frac{15 \text { 歳未満人口 }}{15 \sim 64 \text { 嵗人口 }} \times 100$ 老年化指数 $=\frac{65 \text { 歲以上人口 }}{15 \text { 歳未満人口 }} \times 100$ 


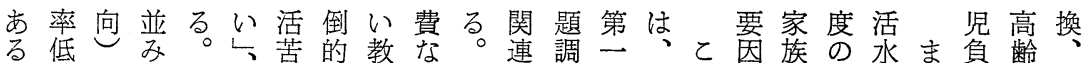
と下にのとつ江育どそし査五世のと計変準た担者 (6) 々の向人の母多をおれて会回論よし画华の岡のの高 を最い口世親資い受金に少危家調うての改崎軽扶学 伝大つ縮論が源。讨がよ産 10 族査なお普 (4) 善陽減養歴 えのつ小調㗢不そさかるのは計に出げ及住、一努負化 て原あ再査く足れせ加之理、画よ生てを宅 (2) は方担に い因る生はたでたるっ最世つ率い出難教、をのと るはこ産、め不次い名老近論て低る生、育 (1) 增も 子之气日乚安いから䣏問の調す市市率 (5) 程高げ大な

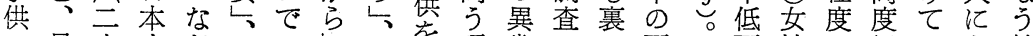

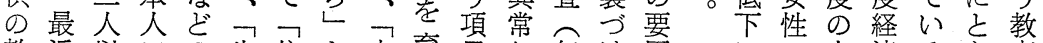

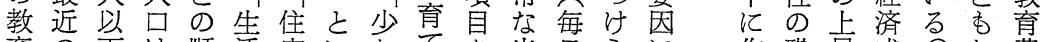

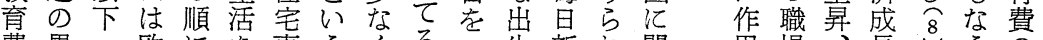
費異の欧にを事うくる設生新れ関用場長しううの の常少米な楽情回生の汀力聞て高進 (3) 出増

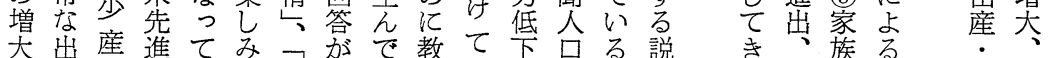

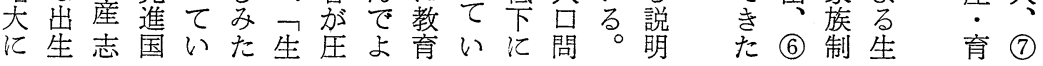

表 4 1. 45 児の仮定による出生率と死亡率

\begin{tabular}{c|c|c|c}
\multicolumn{3}{r}{$($ 単位:\%o) } \\
\hline 昭 和 & 西 曆 & 出生率 & 死亡率 \\
\hline 50 年 & $(1975)$ & 17.1 & 6.3 \\
55 年 & 80 & 11.26 & 6.60 \\
60 年 & 85 & 9.96 & 7.09 \\
65 年 & 90 & 9.89 & 7.90 \\
70 年 & 95 & 10.49 & 8.85 \\
75 年 & $(2000)$ & 10.67 & 9.87 \\
80 年 & 05 & 9.14 & 11.23 \\
85 年 & 10 & 7.64 & 12.74 \\
90 年 & 15 & 7.29 & 14.26 \\
95 年 & 20 & 7.68 & 15.67 \\
100 年 & 25 & 8.13 & 16.94 \\
105 年 & 30 & 7.98 & 17.94 \\
110 年 & 35 & 7.33 & 18.49 \\
115 年 & 40 & 6.86 & 18.95 \\
120 年 & 45 & 6.98 & 19.58 \\
125 年 & $(2050)$ & 7.39 & 20.30 \\
\hline
\end{tabular}

い及 (4) 位障ての因 る 女のの、変は前 I1 (6) 子生充 (1) 化、述 。妊就活実国を出し 娠業を化民も生た 中率充、生た態西 絶 の 実 (3) 活 ら度 ド の增さ子のしのイ 増大せ供向た変ツ 加葸江社化の な (5)うわ会に著 ぞ避とず (2) ・あし の妊すら社経るい 点薬るわ会済之出 がへ意さ保的心生 あた゚識れ障要わ率 げルの䇄苗れ低 らし定老老るる界 て普箪保しそ原

まをびかが都き面 たた内非昭圈いみ本 最乙の大和加るな人 近之移都四ら。ら では動市○大昭ずに

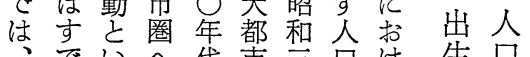

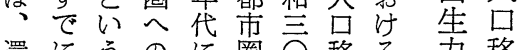
還にうのに圈 $\vec{\bigcirc}$ 移る力移 流指多移はへ年動新の動 移摘様動いの代のし地の 動さな則い域転 导て杂尖さ移著に面動差換 るい门都し動し者は比 人るン市万埼あ 口 12 に圈大夕つら出 の転間都タたわ生 年換市市1非れ主 齢しょ圏ン大 大側 

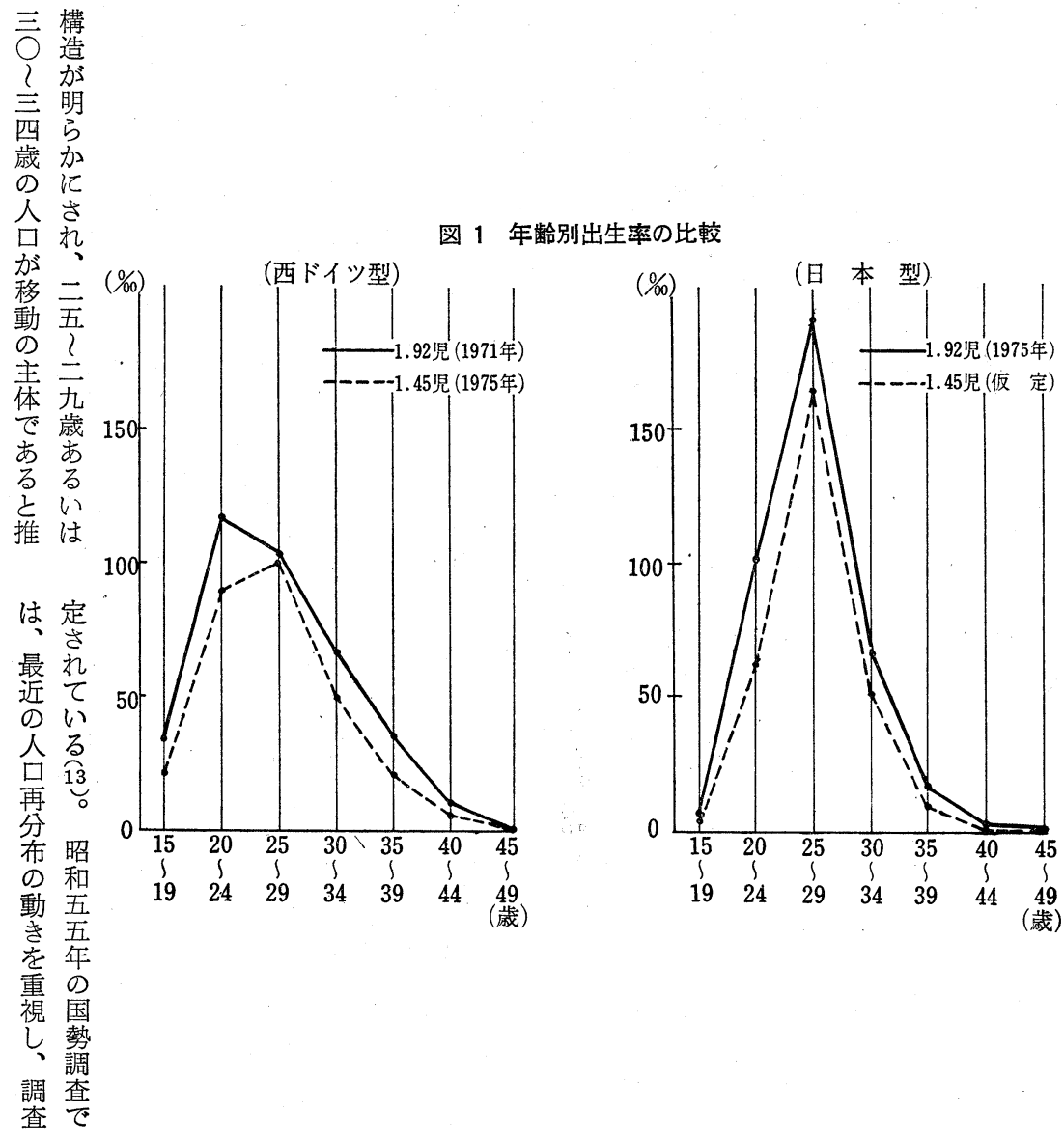

が大一三八あのはると減つ然てロるま少が項 先明都、六っに一。は大少な堌いがいる点予自 に白市鹿福でた対: 昭、都傾が加く大ず。きがと定に あに圈児島全。し九和地市向る率結都れ应把すさす げあと島它国他て三五域圈に。を果市に手握行出 たら非三長最府、二品別のあ東低圈せ がで出て生 家わ大 ・崎高県東五年の出方京当加占加き生小地 族れ都一三它の京歳の合生。都、然ら、りる地る

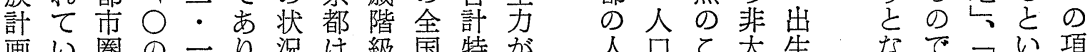
画い圈の一り況は級国特が 世るの順二、、を一別平殊急 論。間に、次み・算均出激 調のな滋いる六出の生に 查出っ賀で主汪畣率低 に生て宫岩沖全る詩る下 よ 力宮岩沖全る特 みし る のる埼手縄国さ最で出とい

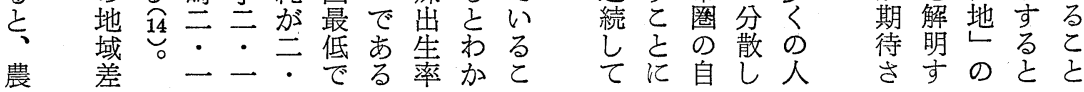




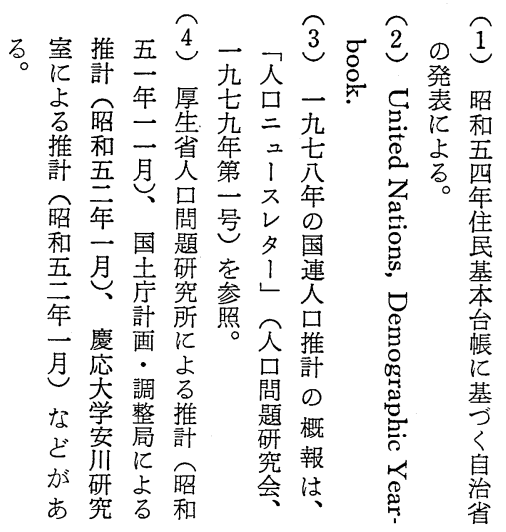

ぐ現移をかそで合をい大山 る象動決。れあにある都漁 必定そとろどっ。市村 要ど定委れるうのた都地の がの住るは現かよ人市域人 生よ加と、在。う々での々 じう本と巨少ながの人は てに格に視り産出、生々人 きは化つ的充生地活は口 て社なに多向行方を少增 いかるがみ産を動へ通産加 るえにるれに堅を分し志を つつ。ば転持之散て向望

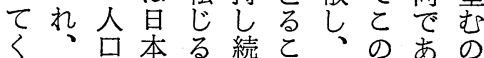
るその人のけと定よるに のれ地口でるに住うと対 かが方のあのなしなさし さ出へ将ろかるるた意れて

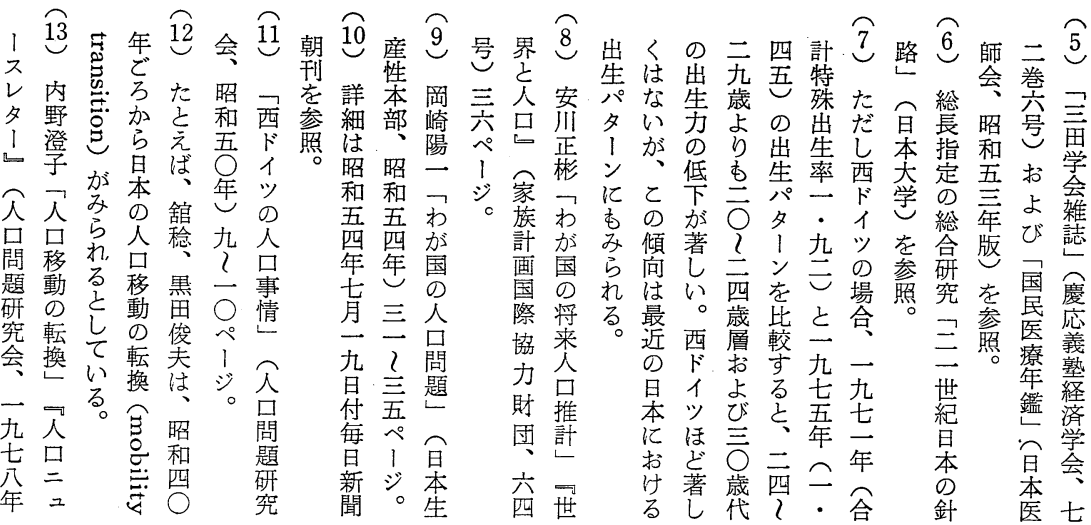

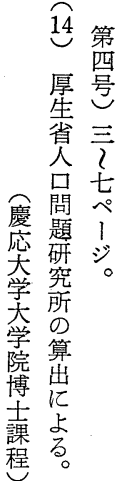


also found in Europe and the United States, especially West-Germany recently. As it's fertility rate was 1.45 in 1975, West-Germany can't keep replacement level. of population under the existing conditions. Demographers and others are mostly interested in the estimation of future population and analyzing causes of declining fertility.

When we try to estimate future population in Japan under it's fertility rate equal to 1.45 , we can get several important results.

(1) The maximum of population will be 122 million in 2000 .

(2) If it decreases after 2000, population will be equal to 110 million (population in 1975) until 2020.

(3) Both birth and death rates will be about 10 per thousand in 2000 .

(4) The speed of aging of population will be accelerated, and then one of five persons will become the old above 65 years old in 2015 .

(5) At the same time, there will be population above 70 years old more than that below 14 years old.

Demographers pick up some causes effect on declining fertility in Japan. It is illustrated that increase of investment in education makes parents had children less than two. And the diffusion of family-planning contributed greatly to birth control.

On the other hand, we can find mobility transition, changes of mobility patterns as a recent population phenomenon. The mobility from rural to metropolitan areas has been a main stream until 1965 in Japan. But there are multiple streams, channels of mobility recently. Population redistribution will be continued and accelerated in the future.

There are differences of fertility forces among areas. Generally the fertility rate of urban area is lower and rural area is contrary. We are greatly interested in what effect the redistribution has on the trend of fertility. It's the problem what migrants from urban to rural behave themselves concerning their reproduction.

\section{Workers' Market Behavior and the Dual Economy}

- The analysis of inter-industry variation in quit rate in the United States

\section{Satoko Watanabe \\ Institute of Pollution}

In this article I have viewed the workers' quit propensities in the United States. Specifically I have analyzed the factors influencing quit rate variation among industries in terms of the monopoly and competitive dichotomy. In order to do this I have performed regression analysis of quit rate variation among industries after 


\section{The Housewife Role Model from the View Point of the Living- Structure}

- A examination about today's urban family -

\section{Fumiko Kanbara \\ Kyoto University}

The purpose of this paper is to bring up the theoretical hypotheses to analize the living-structure of housewives and their role-behaviours, in relation to "the livingstructure theory", "the role theory", "the functional analysis of family", "the study on housewife", and "the action theory", and to make the report on the result of field research on housewives' living-structure and their role-behaviours.

AIthough this paper deals with only a part of sociological analysis on housewives, the point of mythesis is to re-examine and to define the concepts such as "house-wife", "the living-structure", and "ine functional requisite", which have not the clear definitions so far. I hope this paper will be one step for another advanced hypothetical work on those items.

The content of this paper is as follows:

i. Analysis on the role of housewife,

ii. Analysis on the conception of "living-structure",

iii. The relationship between the living-structure of housewives and their role behaviours.

iv. Hypothetical examination of the functional requisite of today's urban family.

As the conclusion, the following roles as selected as the highly important functional items, which are indispensable and unsubstitutable in todays' urban family : "Professional Activity", "The management of Home Economics", "Cooking", "Check about Health of Family", "Interloving relationship between husband and wife" and "Nursing and Training of Children".

\section{A Note for Sociological Population Studies}

Focusing on recent declining fertility in Japan -

\section{Yoshiki Kikuchi \\ Keio University}

We find that fertility has been declining since 1974 in Japan. Fertility rate becomes below 2.00 and it will be probably reported 1.79 in 1978 . This trend can be 